\title{
A Thematic Analysis of Provider Comparisons of Telemedicine Satisfaction Measures
}

\author{
Robert Garcia \\ DePaul University \\ rgarci11@depaul.edu
}

\author{
Peter Kallio \\ Rosalind Franklin University \\ peter.kallio@rosalindfranklin.edu
}

\author{
Olayele Adelakun \\ DePaul University \\ oadelaku@depaul.edu
}

\begin{abstract}
Satisfaction remains one of the most frequently used and inconsistent measures in Information Systems research. These inconsistencies can create challenges for interpreting the results of satisfaction measures. These challenges are noticeable in the telemedicine literature where researchers often rely on single item measures of overall satisfaction. While researchers have attempted to address these issues by studying satisfaction's measurements and methodologies there remain gaps in the knowledge on how variations in measures may be interpreted regarding decision making. This research seeks to contribute to the knowledge in this area by investigating medical provider perspectives on single versus multidimensional measures of telemedicine satisfaction. Through a thematic analysis this research shows variations and similarities in decision making between measures across eleven themes. The results show not only variations in views but indicate subjective experiential interpretations of results. Findings along with implications for researchers and medical providers are discussed.
\end{abstract}

\section{Introduction}

Despite the long history in Information Systems (IS) research of using user satisfaction to measure the success of systems, there is a great deal of uncertainty around satisfaction [1]. Satisfaction remains a loosely defined term [2]. This can present challenges for interpreting the results of satisfaction measures. For example, evaluations may demonstrate high levels of satisfaction but if uncertainty exists around satisfaction how should decision makers interpret the results meaning? The challenges stemming from the uncertainty of satisfaction are apparent when evaluating complex information systems such as telemedicine. Providing remote medical care across geographic distances otherwise known as telemedicine involves many different components [3]. From the variety of technologies used to the various interactions with doctors, nurses, technical support and other staff, there are several factors that contribute to a patient's experience. Yet measures such as overall satisfaction that are commonly used in telemedicine research may not capture this complexity. In medical practice for instance high levels of satisfaction may correlate with various medical outcomes and behaviors [4].

While single measures of satisfaction may be considered good enough for some research, studies have shown that patient satisfaction is a complex and multi-dimensional construct [5]. Indeed, there have been various studies in the telemedicine, IS and medical literature that have investigated or called for investigations into satisfaction's complexities and the different factors that inform it [2]. Among the reasons for these calls, particularly in telemedicine studies, is that there is often no agreement on the dimensions used for satisfaction's evaluation [6]. Between single measures of satisfaction and different variations of dimensional satisfaction, evaluations can be difficult to conduct and interpret.

With the continued expansion of telemedicine services, particularly during the COVID-19 pandemic, it is more important now than ever that decision makers can make sense of telemedicine evaluations [7]. Many medical institutions and private practitioners began using telemedicine during the pandemic as a means of increasing accessibility to care [8]. This has created a larger than expected expansion in telemedicine usage. With a variety of different products available and the potential different medical services that can be offered through telemedicine there is a need to evaluate it, its impacts and variations in services and technologies. Yet uncertainty exists in which measurements should be used and how they should be interpreted, especially when comparing systems. The research community has attempted various methods to help address some of these needs and challenges. Some researchers have attempted to address the dimensionality of satisfaction by identifying the factors that contribute to it [2]. Others have attempted to design new measurements instruments that evaluate multiple criteria that informs patient satisfaction with telemedicine services [9]. 
However other researchers continue to rely on single measures of patient overall satisfaction [10].

The reasons for this are unclear. It is possible that some researchers are just unaware of this work or the dimensionality of satisfaction. However, it is also possible that these single measures of overall satisfaction are just good enough indicators for specific research objectives. Some research suggests that there may be limited empirical differences in the measures of satisfaction. Yet others caution that reliance on single measures may lead to overestimations in reported satisfaction results [11]. However, as satisfaction and its evaluations can vary based on context it is unclear how this relates to telemedicine research. It is uncertain whether the complexity of telemedicine and involvement of various actors not only in usage but in decision making may result in different perspectives based on measures. In medical settings for instance providers are seen as the gatekeepers for new technologies [12]. Yet provider evaluations are often formed based on their views of patient outcomes and experiences [13]. It is therefore important to understand provider perspectives on the value of dimensional and single measure items of patient telemedicine satisfaction. Yet there remain gaps in the literature as the differences between provider perspectives on these different measurements and how they impact decision making is seldom considered.

This research will contribute to the knowledge of telemedicine satisfaction research by providing new insights to help fill in this gap. This research will specifically seek to provide insight into the question of how medical providers view multi-dimensional versus single item overall measures of patient satisfaction with telemedicine. This will be done to contribute to the knowledge on the underlying problem related to interpretation of the satisfaction measure. The research explores this by examining provider views at the Zablocki Veteran's Affairs Hospital (ZVAMC) in the US. Through a thematic analysis of provider interviews of patient satisfaction measures, this research provides new insight into the ways providers view measures. While the scope of this research is limited to the views at one institution the results of the study contribute to the knowledge by providing new insights into provider perspectives on decision making that can be used by both IS researchers and decision makers.

\section{Literature Review}

For decision makers, the satisfaction of patients remains a critical tool for evaluating telemedicine services. Yet because of the difficulties with understanding satisfaction the knowledge gained from its evaluation can potentially vary in value. The objective of this review will be to describe satisfaction and these challenges, ways these challenges are being met in telemedicine studies, and gaps in the current knowledge. Satisfaction has evolved alongside the IS field and is generally considered one of the field's more flexible, easily measured and reliable measures [14]. However, despite its widespread use, satisfaction is a difficult concept to define and there are inconsistencies in its conceptualization [4]. Views on the meaning of satisfaction often evolve and vary based on domain and context. Variations exist on how satisfaction is defined in the literature around human behavioral, psychological, physiological, and organizational aspects. Early research in business and marketing described satisfaction as a function of a consumer's expectations and influencer on the postpurchase attitude [15]. This attitude was seen to link to some post-purchasing behavior or intention. Yet no consensus on satisfaction's meaning was ever developed. Since at least the early 2000s and likely earlier researchers in marketing and management have continued to grapple with questions on the definition of satisfaction and its meaning [16].

Over time, the meaning of satisfaction and its perception has evolved to consider additional aspects of the consumer experience [15]. Among these aspects that researchers in various fields are more likely to now consider are the cognitive and emotional processes that both influence and result from satisfaction. These psychological considerations are particularly important when evaluating the patient experience [5]. Yet research in the medical field shows that there are also physiological aspects to consider such as the influence of and potential effects of satisfaction on clinical outcome [17]. These variations in views of satisfaction can affect the results of research limiting understandings and contributions that can be made [16]. Research has shown that satisfaction exists as a complex and multi-dimensional concept [1]. Yet there is little agreement on what these satisfaction dimensions are or how to measure them. Variations in satisfaction's measures can make comparisons difficult as it can be unclear whether studies are indeed comparing the same constructs [1]. Studies in IS have acknowledged the need for fully defining similar complex constructs and their dimensions [18]. Recent studies have shown how different levels of satisfaction measurements from overall to measurements of IS component and their individual attributes can potentially provide different views of systems [14]. However, many studies, particularly those that pertain to specific IS such as telemedicine often do not take satisfaction's complexity into consideration.

Research into telemedicine is often criticized because of challenges with the measurement of 
satisfaction. Concerns over the validity and reliability of satisfaction measures along with measurement methodologies are common in the telemedicine literature [19]. Some of these issues can be linked to the lack of standardized measures for satisfaction as it leaves interpretation up to individual researchers and their decisions on which measures should be considered [5]. This often leads to cases where researchers are defining new measures for specific studies or merging and modifying items from previous questionnaires [20]. In other cases, researchers are relying on single measures of overall satisfaction that do not consider other possible dimensions of the construct $[10,21]$. This creates a state in telemedicine research where evaluations and comparisons of studies and measures may be difficult.

Researchers have approached these issues in several different ways. Some researchers have focused on describing the problems with telemedicine methodologies and have provided recommendations such as standardization and dimensional considerations for improvements [22]. Other researchers have looked more critically at the methodologies and ways in which satisfaction evaluations can be improved [23]. Heeding these calls for improvements several researchers have focused their efforts on improving the survey instruments being used for evaluating telemedicine satisfaction [9]. Others have focused on examining common measures from the literature and instruments that can potentially improve the evaluated determinants [2]. Several researchers have also attempted to develop new or revised models to assist in telemedicine evaluations [24]. While these efforts have the potential to aid in improving the validity and aspects for consideration in evaluations there are still several gaps in need of further research. One of these specifically centers around views between the overall satisfaction measure and the more comprehensive multi-dimensional view of satisfaction. This is because it is unclear as to whether overall satisfaction really amounts to the same thing as what is represented by different attributes researchers evaluate for satisfaction. Some research has shown limited difference in the predictive validity between multiple item and single measures [25]. However, Busacca and Padula [11] demonstrated the disconnect between the performance of overall satisfaction and attribute measurements of satisfaction. Other researchers also demonstrate a disconnect between these measures and urge caution when relying on single measures of satisfaction for decision making [26].

While their research provides implications on the appropriateness of decisions that may be affected by these quantitative variations, gaps remain in the how these different views may be interpreted. Some research has touched on the differences between decision maker perspectives on these different measurements, but the results remain limited. Liu, et al. [27] for instance demonstrated challenges with interpretations of patient satisfaction measurements. They conclude that without more development on the satisfaction measure practitioners would face difficulty with maximizing patient satisfaction. While this study touched on management considerations of maximizing satisfaction, other studies have provided some indicators of how decisions could be impacted. Through a comparison of measures Oshagbemi [28] showed that overall satisfaction may provide an overestimated view of satisfaction and provide decision makers with a more positive views of systems than multi-dimensional measures may indicate. This suggests that there are additional impacts on decision making based on the variations of measures. More recently researchers have attempted to address some of these considerations through studies that attempt to identify the determinants of overall satisfaction [14, 29]. By closing the distance between attributes and one-dimensional performance measures, researchers may be able address some of the challenges between the measures. Despite these efforts gaps remain in the knowledge on how decision makers view satisfaction measurements and how differences in measurements may impact their decisions. Gaps in the knowledge such as these can have an impact on the types of decisions that are made and therefore demonstrate a need for additional research into their impacts. This is particularly important in telemedicine research where evaluations of overall satisfaction are common and there is a need to compare evaluations.

\section{Methodology}

The objective of this research was to explore medical provider perspectives of single versus multidimensional measures of patient satisfaction with telemedicine. This research specifically sought to understand the kind of value providers placed on satisfaction measures and their potential impact on decision making. This research sought to accomplish this by obtaining qualitative feedback from providers on their views of the results of measures.

Qualitative methods were used to gather and analyze non-numerical human centered data [30]. They are typically valued for their descriptive and explanatory power that can aid in understanding the why and how of phenomenon along with interpretations of meaning [31]. Qualitative methods often require more resources to collect comparable quantitative sample sizes and may have limited generalizability. Despite these limitations qualitative 
methods were viewed as ideal for several reasons. First, because of the variations and lack of agreement on satisfaction it is important that providers contribute their interpretations of the meaning of results. Second there are no established criteria for what subjective decisions providers may make or what if any value they may place on measures. It was determined that medical providers would be best positioned to provide insight for the study. While there are a variety of other decision makers, medical providers are often viewed as the gatekeepers for telemedicine [12]. Further, because of their direct interactions with patients through the telemedicine system they are more likely to understand different facets of the patient experience. To obtain the data, medical providers would be interviewed using semi-structured open-ended questions. Interviews are considered appropriate for studies in which the research goals are to obtain unobservable data such as feelings and interpretations of phenomenon [32].

For qualitative data collection, studies often rely on continuing data collection until saturation occurs [33]. Saturation can begin occurring at various times depending on the study and context. During data collection for this study several recurring themes were identified after interviewing six participants. At nine participants most of the themes seemed to be recurring and limited new information was obtained. This follows descriptions in the literature where the greatest code saturation begins occurring early in a study when using more controlled techniques. A study by Guest, et al. [34] demonstrated how at around twelve semistructured interviews the majority of codes needed for thematic analysis are derived. Additional interviews were conducted beyond the twelve recommended. In total fifteen interviews were conducted at which point no new information was obtained. All fifteen of the recruited participants were medical doctors that provided telemedicine services to patients at the hospital. No compensation was provided for participation.

Interviews were conducted in offices at the ZVAMC that serves over 800,000 annual visits in the US state of Wisconsin. The hospital provides telemedicine in collaboration with four remote regional community-based outpatient clinics or CBOCs. Communications include videoconferencing and storeand-forward equipment. Researchers did not consider differences between CBOC and direct providers. Interviews were conducted by a University cocollaborator. Each was less than 20 minutes. Interviews were conducted with approval from both the DePaul University and ZVAMC internal review boards. Interviews were audio recorded and the recordings were transcribed before destruction. After consent was obtained two sets of interview procedures were conducted: one for single-measure and the other dimensional satisfaction. In this case some participants would first receive the overall satisfaction results and others the dimensional results. This was done in a randomized order to limit the potential bias in results from viewing results in a specific order. This was due to concerns that participants could potentially form opinions on the measures mainly from comparing differences in the visual depictions rather than the results they represented. This is also the reason why a direct side-by-side comparison was deemed inappropriate. The questions were determined by the researchers based on the goals of understanding provider views on measures, decision making and their potential value. Four questions were asked:

Q1. What do you feel these results mean in regard to the telemedicine services?

Q2. How do you think these results can help you in making decisions about telemedicine?

Q3. What kind of decisions about telemedicine do you think these results would help you to make?

Q4. How valuable do you feel these results are to decision making and what kind of value do you think you can get from them?

The questions were tested on a small sample of ten students. Due to the limited time providers were able to dedicate to each interview and constraints placed, the final question combined two inquiries. While generally not recommended, this was viewed as adequate in this case as during testing it was generally viewed to elicit a simple response. After the questions were asked the process would repeat for the second set of results. After both sets of procedures, the interviewer would ask follow-up questions and a debriefing was conducted. The results of interviews were analyzed through an inductive thematic analysis by two reviewers with a third serving as a judge [35]. Thematic analyses are considered flexible and useful methods for deriving patterns of meaning from unstructured data in qualitative results. Using an inductive approach, patterns can be developed from the data itself rather than relying on theory. Thematic analysis is conducted using the following steps:

1. Familiarize yourself with the data.

2. Generating initial codes

3. Searching for themes

4. Reviewing themes

5. Defining and naming themes

6. Producing the report

This approach was seen as ideal for several reasons. First because of the uncertainty around these 
measures it is difficult to link subjective views by providers on decision making to existing theory. Inductive thematic analysis creates shared meaning from a combination of various views. This allows for a flexible approach towards capturing provider perspectives directly without the influence of theoretical biases by researchers. Given the high degree of uncertainty around the potential results these biases could potentially lead to loss of important findings limiting the value of deductive methods.

\section{Results}

Participants were provided results of a telemedicine satisfaction survey of patient views of single and multidimensional satisfaction. The survey was conducted of seventy-five patient participants taken at the hospital before the interviews were conducted. Figure 1 and figure 2 below show the results of the survey provided to the medical providers.

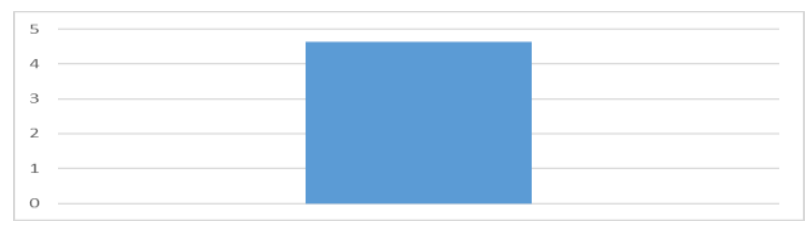

Figure 1. Overall satisfaction results

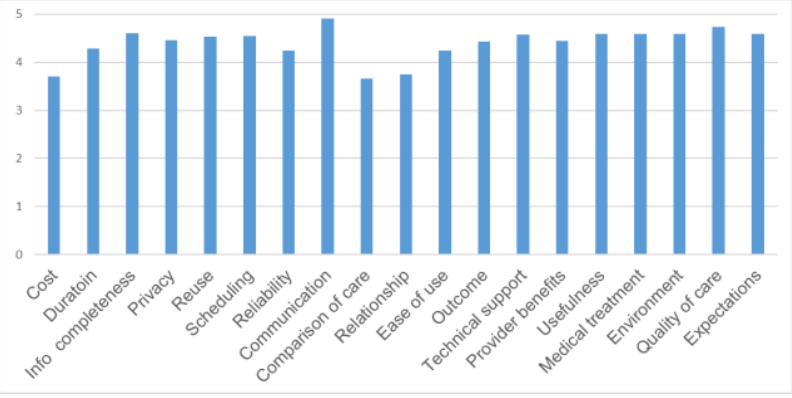

Figure 2. Multi-dimensional results

To aid in synthesizing the results an open coding procedure was conducted. The procedure was used to extract relevant concepts from the extracted text by breaking down the responses per question. Thirteen codes were derived from the results for overall satisfaction. Table 1 below shows the results and sample quotes that demonstrate some of the properties.

Table 1. Coding results of measures

\begin{tabular}{|l|l|l|}
\hline Open code & Properties & Sample quote \\
\hline $\begin{array}{l}\text { Attached } \\
\text { meaning }\end{array}$ & $\begin{array}{l}\text { Deriving } \\
\text { meaning, } \\
\text { interpreting }\end{array}$ & $\begin{array}{l}\text { Sounds like it's a } \\
\text { pretty effective } \\
\text { convenient service }\end{array}$ \\
\hline
\end{tabular}

\begin{tabular}{|c|c|c|}
\hline Actionable & $\begin{array}{l}\text { Results suggest } \\
\text { an outcome or } \\
\text { resulting action }\end{array}$ & $\begin{array}{l}\text { Telemedicine is } \\
\text { something that we } \\
\text { should continue to try } \\
\text { to provide and maybe } \\
\text { expand on }\end{array}$ \\
\hline $\begin{array}{l}\text { Value } \\
\text { based }\end{array}$ & $\begin{array}{l}\text { Results based. } \\
\text { Looks for } \\
\text { quantitative } \\
\text { meaning } \\
\end{array}$ & $\begin{array}{l}\text { It looks like it was } \\
\text { ranked fairly high so } \\
\text { to me that would be a } \\
\text { positive }\end{array}$ \\
\hline $\begin{array}{l}\text { Low level } \\
\text { itemized }\end{array}$ & $\begin{array}{l}\text { Views items } \\
\text { individually. } \\
\text { Focus on } \\
\text { differences of } \\
\text { measures }\end{array}$ & $\begin{array}{l}\text { It sounds like they } \\
\text { feel as though the } \\
\text { care they are } \\
\text { receiving the } \\
\text { telemedicine is not as } \\
\text { good as it would be in } \\
\text { person }\end{array}$ \\
\hline $\begin{array}{l}\text { High level } \\
\text { relational }\end{array}$ & $\begin{array}{l}\text { Views of totality } \\
\text { of results. Lower } \\
\text { values influence } \\
\text { perceptions of } \\
\text { higher values }\end{array}$ & $\begin{array}{l}\text { There's a lot of pros } \\
\text { and not very many } \\
\text { negative based upon } \\
\text { this graph }\end{array}$ \\
\hline $\begin{array}{l}\text { Rationalize } \\
\text { and justify }\end{array}$ & $\begin{array}{l}\text { Rationalize } \\
\text { results based on } \\
\text { experiences, } \\
\text { attempt to find } \\
\text { reasons for } \\
\text { results } \\
\end{array}$ & $\begin{array}{l}\text { Just from my } \\
\text { experiences with the } \\
\text { telemedicine patients } \\
\text { you know they're } \\
\text { very glad }\end{array}$ \\
\hline $\begin{array}{l}\text { Conf } \\
\text { evalu }\end{array}$ & $\begin{array}{l}\text { Confirming } \\
\text { beliefs, justifying } \\
\text { efforts, views of } \\
\text { acceptance } \\
\end{array}$ & $\begin{array}{l}\text { Well I guess I would } \\
\text { be encouraged to } \\
\text { continue using it }\end{array}$ \\
\hline $\begin{array}{l}\text { Utilization } \\
\text { evaluation }\end{array}$ & $\begin{array}{l}\text { Encourage to use } \\
\text { telemedicine, } \\
\text { views service as } \\
\text { an option, shapes } \\
\text { provider and } \\
\text { patient views }\end{array}$ & $\begin{array}{l}\text { I guess I would } \\
\text { maybe offer it to } \\
\text { more patients given } \\
\text { the fact that it looks } \\
\text { like overall it's a } \\
\text { fairly high level of } \\
\text { satisfaction }\end{array}$ \\
\hline $\begin{array}{l}\text { Rating } \\
\text { evaluation }\end{array}$ & $\begin{array}{l}\text { Ratings results } \\
\text { are considered, } \\
\text { views shaped by } \\
\text { results }\end{array}$ & $\begin{array}{l}\text { I think that our } \\
\text { process would be } \\
\text { working well cause } \\
\text { they scored us high }\end{array}$ \\
\hline $\begin{array}{l}\text { Confirm } \\
\text { option }\end{array}$ & $\begin{array}{l}\text { Confirming } \\
\text { existing views or } \\
\text { practices }\end{array}$ & $\begin{array}{l}\text { It kind of supports } \\
\text { why I think it's a } \\
\text { good option you } \\
\text { know for some } \\
\text { patients }\end{array}$ \\
\hline $\begin{array}{l}\text { Comparing } \\
\text { results }\end{array}$ & $\begin{array}{l}\text { Views on face to } \\
\text { face versus } \\
\text { telemedicine } \\
\text { may be based on } \\
\text { results }\end{array}$ & $\begin{array}{l}\text { I would say it's } \\
\text { practically the same } \\
\text { as being face to face } \\
\text { with a patient in the } \\
\text { room }\end{array}$ \\
\hline $\begin{array}{l}\text { Implies } \\
\text { action } \\
\end{array}$ & $\begin{array}{l}\text { Results suggest } \\
\text { action needed, }\end{array}$ & $\begin{array}{l}\text { Just trying to improve } \\
\text { the relationship that I }\end{array}$ \\
\hline
\end{tabular}




\begin{tabular}{|c|c|c|}
\hline & $\begin{array}{l}\text { views of poorer } \\
\text { results as } \\
\text { needing } \\
\text { improvement } \\
\end{array}$ & $\begin{array}{l}\text { establish with the } \\
\text { participant during } \\
\text { that time. }\end{array}$ \\
\hline $\begin{array}{l}\text { Usage } \\
\text { decisions }\end{array}$ & $\begin{array}{l}\text { Shapes views on } \\
\text { using, addressing } \\
\text { uncertainty }\end{array}$ & $\begin{array}{l}\text { That most patients are } \\
\text { satisfied with it so } \\
\text { that it is an option to } \\
\text { at least try at least } \\
\text { once }\end{array}$ \\
\hline $\begin{array}{l}\text { Rating } \\
\text { decisions }\end{array}$ & $\begin{array}{l}\text { Views on what } \\
\text { the values } \\
\text { represent }\end{array}$ & $\begin{array}{l}\text { It seems like the } \\
\text { setup that were doing } \\
\text { seems to be } \\
\text { satisfactory }\end{array}$ \\
\hline $\begin{array}{l}\text { Decision } \\
\text { challenges }\end{array}$ & $\begin{array}{l}\text { Insufficiency of } \\
\text { data for } \\
\text { decisions, other } \\
\text { data } \\
\text { considerations } \\
\end{array}$ & $\begin{array}{l}\text { It's kind of a snippet } \\
\text { of information I don't } \\
\text { know if you can draw } \\
\text { a conclusion }\end{array}$ \\
\hline $\begin{array}{l}\text { Limited } \\
\text { impact }\end{array}$ & $\begin{array}{l}\text { Results have } \\
\text { limited impact, } \\
\text { based on current } \\
\text { views, } \\
\text { experience and } \\
\text { practice }\end{array}$ & $\begin{array}{l}\text { It doesn't necessarily } \\
\text { change my opinion of } \\
\text { it cause I already use } \\
\text { it and like it }\end{array}$ \\
\hline $\begin{array}{l}\text { Uncertain } \\
\text { changes }\end{array}$ & $\begin{array}{l}\text { Acknowledge } \\
\text { improvements } \\
\text { needed, uncertain } \\
\text { on what } \\
\text { improvements }\end{array}$ & $\begin{array}{l}\text { You know maybe } \\
\text { (pause) might adjust I } \\
\text { mean it might change } \\
\text { it looks like some of } \\
\text { the things they look } \\
\text { at is umm } \\
\end{array}$ \\
\hline $\begin{array}{l}\text { Specific } \\
\text { ideas }\end{array}$ & $\begin{array}{l}\text { Specifies specific } \\
\text { improvement, } \\
\text { ideas based on } \\
\text { analysis of why } \\
\text { problem } \\
\text { occurred }\end{array}$ & $\begin{array}{l}\text { Maybe I would say } \\
\text { be more interactive } \\
\text { with the patients not } \\
\text { looking at the } \\
\text { monitors looking } \\
\text { away from the } \\
\text { camera and stuff like } \\
\text { that }\end{array}$ \\
\hline Rationalize & $\begin{array}{l}\text { Explain or } \\
\text { understand } \\
\text { behavior, } \\
\text { examines data } \\
\text { considering } \\
\text { experiences }\end{array}$ & $\begin{array}{l}\text { Well, I think the } \\
\text { relationship thing is a } \\
\text { little lower than I } \\
\text { expected it to be I } \\
\text { don't know if that's } \\
\text { because they don't } \\
\text { feel a connection with } \\
\text { the provider over the } \\
\text { tele-type visit }\end{array}$ \\
\hline $\begin{array}{l}\text { Experience } \\
\text { preferred }\end{array}$ & $\begin{array}{l}\text { Personal } \\
\text { experiences } \\
\text { valued, } \\
\text { ownership of } \\
\text { decision making, } \\
\text { data should not } \\
\text { drive decisions } \\
\end{array}$ & $\begin{array}{l}\text { I mean it looks like } \\
\text { people may be } \\
\text { satisfied but I would } \\
\text { have to see what my } \\
\text { patient was }\end{array}$ \\
\hline
\end{tabular}

\begin{tabular}{|c|c|c|}
\hline $\begin{array}{l}\text { Limited } \\
\text { information }\end{array}$ & $\begin{array}{l}\text { Information } \\
\text { deficiencies, } \\
\text { additional data } \\
\text { needed }\end{array}$ & $\begin{array}{l}\text { I don't know if I can } \\
\text { take much from it } \\
\text { (laughing) sorry }\end{array}$ \\
\hline $\begin{array}{l}\text { Usage } \\
\text { value }\end{array}$ & $\begin{array}{l}\text { Data as a } \\
\text { qualifier for } \\
\text { usage, } \\
\text { encourages usage }\end{array}$ & $\begin{array}{l}\text { I think it's important } \\
\text { to know that patients } \\
\text { are satisfied and } \\
\text { that's a big uh } \\
\text { qualifier for me }\end{array}$ \\
\hline $\begin{array}{l}\text { Reflect and } \\
\text { confirm }\end{array}$ & $\begin{array}{l}\text { Used to evaluate } \\
\text { efforts, appeases } \\
\text { concerns, eases } \\
\text { uncertainty }\end{array}$ & $\begin{array}{l}\text { This makes me feel } \\
\text { like that that work is } \\
\text { worthwhile because } \\
\text { the patients are } \\
\text { clearly satisfied with } \\
\text { the product }\end{array}$ \\
\hline Analytical & $\begin{array}{l}\text { Examine results } \\
\text { in term of } \\
\text { experience, uses } \\
\text { results to identify } \\
\text { issues }\end{array}$ & $\begin{array}{l}\text { It's important to see } \\
\text { what where the } \\
\text { patients see the } \\
\text { problem like in this } \\
\text { graph }\end{array}$ \\
\hline Reassure & $\begin{array}{l}\text { Results used to } \\
\text { confirm view, } \\
\text { results help } \\
\text { reassure feelings } \\
\end{array}$ & $\begin{array}{l}\text { I guess most of its } \\
\text { just reassuring that } \\
\text { patients seem to be } \\
\text { pretty pleased with it }\end{array}$ \\
\hline Improve & $\begin{array}{l}\text { Results suggest } \\
\text { areas of } \\
\text { improvement, } \\
\text { informs change } \\
\text { versus decision } \\
\text { on uses }\end{array}$ & $\begin{array}{l}\text { If you have this } \\
\text { information it can } \\
\text { help you determine } \\
\text { what things we have } \\
\text { to improve upon }\end{array}$ \\
\hline
\end{tabular}

Data was further consolidated using an axial coding process to collate codes into themes. Axial codes were derived by examining similarities in described properties. Data per theme were grouped together by examining results for each question based on the measurement type. In total eleven axial codes were derived from the groupings.

Table 2. Axial coding results

\begin{tabular}{|l|l|}
\hline Axial Codes & Open codes \\
\hline $\begin{array}{l}\text { Sufficiency of } \\
\text { results }\end{array}$ & $\begin{array}{l}\text { Decision challenges, limited } \\
\text { information }\end{array}$ \\
\hline $\begin{array}{l}\text { Confirming } \\
\text { choices on usage }\end{array}$ & $\begin{array}{l}\text { Usage decisions, usage values, } \\
\text { utilization evaluation, reflection, } \\
\text { and confirmation, actionable }\end{array}$ \\
\hline $\begin{array}{l}\text { Confirming over } \\
\text { shaping views }\end{array}$ & $\begin{array}{l}\text { Experience preferred, } \\
\text { confirmation evaluation }\end{array}$ \\
\hline $\begin{array}{l}\text { Consider results } \\
\text { based on attached } \\
\text { meaning }\end{array}$ & $\begin{array}{l}\text { Rating evaluation, value based, } \\
\text { rating decisions, attached } \\
\text { meaning }\end{array}$ \\
\hline $\begin{array}{l}\text { Comparative } \\
\text { analysis of results }\end{array}$ & $\begin{array}{l}\text { Low level itemized, high level } \\
\text { relational, analytical, comparing } \\
\text { results }\end{array}$ \\
\hline
\end{tabular}




\begin{tabular}{|l|l|}
\hline $\begin{array}{l}\text { Rationalize results } \\
\text { based on } \\
\text { experiences }\end{array}$ & $\begin{array}{l}\text { Rationalization and justification, } \\
\text { rationalization, rationalize } \\
\text { perceived negatives }\end{array}$ \\
\hline $\begin{array}{l}\text { Confirming and } \\
\text { reassuring beliefs }\end{array}$ & Confirm option, reassurance \\
\hline $\begin{array}{l}\text { Identifying areas } \\
\text { of improvement }\end{array}$ & $\begin{array}{l}\text { Implies action, actionable, } \\
\text { improvement, }\end{array}$ \\
\hline $\begin{array}{l}\text { Levels of } \\
\text { improvement }\end{array}$ & $\begin{array}{l}\text { Uncertain improvements, specific } \\
\text { ideas, limited impact }\end{array}$ \\
\hline $\begin{array}{l}\text { Confirming } \\
\text { choices }\end{array}$ & $\begin{array}{l}\text { Confirmation evaluation, Confirm } \\
\text { option, reassurance }\end{array}$ \\
\hline $\begin{array}{l}\text { Experience based } \\
\text { decisions }\end{array}$ & $\begin{array}{l}\text { Experience preferred, } \\
\text { Rationalization and justification, } \\
\text { rationalization, specific ideas, } \\
\text { limited impact }\end{array}$ \\
\hline
\end{tabular}

Following this a thematic analysis was conducted. During thematic analysis items are grouped and relations examined through the creation of a thematic map. Thematic mapping was used to identify three main categories of relationships between themes. These include those related to single item measures, those related to multi-dimensional items and those that were similar in both. Three were identified for overall satisfaction, four in the multi-dimensional codes, and two were identified between groupings. Table 2 shows the results of the axial coding process and the derived relationship groupings. The resulting themes and their relationships between each other were examined and the final step of naming and defining the themes was conducted. Table 3 shows the results.

Table 3. Theme naming and defining.

\begin{tabular}{|l|l|l|}
\hline Name & Theme & Definition \\
\hline Single item measure & $\begin{array}{l}\text { Confirmatory } \\
\text { nature } \\
\text { views }\end{array}$ & $\begin{array}{l}\text { Confirming } \\
\text { determining views }\end{array}$ \\
\hline $\begin{array}{l}\text { Interpretative } \\
\text { analysis }\end{array}$ & $\begin{array}{l}\text { Consider } \\
\text { confirming but not } \\
\text { results based } \\
\text { on attached } \\
\text { meaning }\end{array}$ & $\begin{array}{l}\text { Results considered } \\
\text { based on meaning } \\
\text { provider's attach to } \\
\text { measures }\end{array}$ \\
\hline Sufficiency & $\begin{array}{l}\text { Sufficiency } \\
\text { of results }\end{array}$ & $\begin{array}{l}\text { Limitations the } \\
\text { results place on the } \\
\text { breadth of decisions } \\
\text { and evaluations that } \\
\text { can be made }\end{array}$ \\
\hline $\begin{array}{l}\text { Multi-dimensional measures } \\
\text { nature }\end{array}$ & $\begin{array}{l}\text { Rationalize } \\
\text { results based } \\
\text { on } \\
\text { experiences }\end{array}$ & $\begin{array}{l}\text { Results that don't } \\
\text { reflect understandings } \\
\text { are rationalized based } \\
\text { on experiences }\end{array}$ \\
\hline
\end{tabular}

\begin{tabular}{|l|l|l|}
\hline $\begin{array}{l}\text { Comparative } \\
\text { analysis }\end{array}$ & $\begin{array}{l}\text { Comparative } \\
\text { analysis of } \\
\text { results }\end{array}$ & $\begin{array}{l}\text { Results add depth and } \\
\text { breadth that can be } \\
\text { analyzed in relation } \\
\text { to experiences }\end{array}$ \\
\hline $\begin{array}{l}\text { Identify } \\
\text { improvement }\end{array}$ & $\begin{array}{l}\text { Identifying } \\
\text { areas of } \\
\text { improvement }\end{array}$ & $\begin{array}{l}\text { Results identify areas } \\
\text { of and the need for } \\
\text { improvement }\end{array}$ \\
\hline $\begin{array}{l}\text { Improvement } \\
\text { levels }\end{array}$ & $\begin{array}{l}\text { Levels of } \\
\text { improvement }\end{array}$ & $\begin{array}{l}\text { Results suggest types } \\
\text { of improvements and } \\
\text { vary from none, } \\
\text { uncertain to specific }\end{array}$ \\
\hline Applicable to both & $\begin{array}{l}\text { Confirming } \\
\text { choices, } \\
\text { confirming } \\
\text { and reassuring } \\
\text { beliefs, } \\
\text { confirming } \\
\text { choices on } \\
\text { usage }\end{array}$ & $\begin{array}{l}\text { Results aid in } \\
\text { decision confirmation } \\
\text { and reassurances }\end{array}$ \\
\hline $\begin{array}{l}\text { Experience } \\
\text { nature }\end{array}$ & $\begin{array}{l}\text { based } \\
\text { decisions } \\
\text { Experience is a } \\
\text { stronger driver of } \\
\text { decisions than } \\
\text { evaluation of results }\end{array}$ \\
\hline
\end{tabular}

\section{Discussion}

Decision makers should easily be able to analyze, interpret and give actionable meaning to the results of evaluations. To contribute to the knowledge around issues related to the interpretation of satisfaction measures, this research evaluated provider perspectives on single and multi-dimensional measures of patient telemedicine satisfaction. Among the unknowns in telemedicine research is whether single measures of overall satisfaction typically used in studies are good enough indicators of satisfaction. Researchers have demonstrated issues with quantitative variations between single measures of satisfaction and multidimensional measures [11]. The results of this study have extended this work by providing evidence for differences and similarities in the ways single and multi-dimensional measures can be qualitatively interpreted by medical doctors.

The results of this research suggest commonalities between the ways in which providers evaluate measures for both single and multi-dimensional satisfaction. This is important as among the challenges with measuring satisfaction is the lack of agreement between measures [22]. The lack of agreement creates challenges where comparisons of research and evaluations are difficult. However, this research found that the similarities were mainly in the ways in which the measurements were used to inform provider 
perspectives and the nature in which they considered results. There was little evidence found that they would lead to similar types of decision making.

Two themes were identified as recurring between both measurements. These themes were reassurance and experiential nature. The findings suggest providers in both cases may view results as a means of confirming and reassuring themselves of choices they make regarding telemedicine. Yet the results suggest despite results of satisfaction measures, some providers will still prefer to rely on their own experiences. These providers view new information whether it is from single or multi-dimensional measures as having less value towards their decision making than what they perceive from their own experiences.

This research also found differences in interpretations of measures and the ways the different measurement types can be used in decision making. In general, single measurements lacked the sufficiency in informing improvements that multi-dimensional measures enabled. Single measurements were also attached meaning by providers, whereas multidimensional measures allowed comparisons. However, providers still generally place greater value on their experiences for both measures. For single measurement items results are used to confirm their views on usage. Whereas for multi-dimensional measures results, providers use results to explain their experiences.

The results suggest that single measurements can lack sufficiency for decision making outside of confirming providers' established decisions on usage. In some cases, providers will interpret results by attaching their own meaning to the measure and what it is supposed to indicate. Based on the results three themes were identified on provider views of the results of single measures of satisfaction. These are confirmatory nature, interpretative analysis, and sufficiency. Given the lack of clarity on the meaning of satisfaction, the overall satisfaction measure can potentially lead to a range of interpretations and decisions [4]. Similar to research by Oshagbemi [28], these findings suggest that the lack of clarity places limits on the types of decisions providers will make. These decisions can be subjectively based on providers' interpretation on satisfaction's meaning and be used for confirming existing views or decisions.

The findings suggest results of multi-dimensional measures provide greater variety of decision making but are limited by a provider's established perspectives. While several studies have called for research into the identification of the factors that inform satisfaction there has been limited studies on understanding the value of multi-dimensional satisfaction in decision making [2]. This research has contributed to this area by identifying several potential themes on provider views of multi-dimensional satisfaction. A total of four themes were identified on provider views of the results of multi-dimensional measures. These were explanatory nature, comparative analysis, identify improvements and improvement levels. The findings from this research show that multi-dimensional considerations can potentially aid providers in identifying the need for improvements. However, the extent to which they can immediately identify specific improvements vary based on provider.

These views of provider experiences can have additional implications for telemedicine practitioners seeking to encourage adoption. Provider views are generally considered shaped by their perspectives on the needs of patients [13]. However, one unexpected outcome of this research is the suggestion that personal experiences and views may overshadow data on patient evaluations. Considering this, the results also suggest different considerations for measurement types. Given the interpretive nature of single measurement items consideration needs to be taken on what meaning providers may derive from the results. Multidimensional measures can add areas for comparison, but providers will still examine them in regard to their experiences. While overall satisfaction measures may lack the same sufficiency for decision making of multidimensional measures they can still be used for reassuring and confirming provider beliefs of their telemedicine usage. Multi-dimensional measures on the other hand can help providers mainly in discussions about potential improvements.

While this research has provided some exploratory findings on the perspectives of provider views of satisfaction measures there are several limitations. First it is unclear on whether there was an impact on the overall satisfaction results given that the results of the evaluation were relatively high. While high levels of satisfaction are common in the telemedicine literature it is possible that levels of dissatisfaction can be obscured from the results [36]. It is unclear whether this might affect provider decisions on overall satisfaction. This would likely not have an impact on views of multi-dimensional measures given their variation. Second as the results were obtained from a small sample from a single institution it is unclear the extent to which perspectives may be shared by other providers. Research has shown that qualitative findings such as this may be limited by contextual factors [37]. It is possible that these differences in views are limited only to providers at the evaluated hospital. This also raises concern over whether there may be variations in views based on provider experience level. At least two of the providers interviewed had limited experience with telemedicine, however all had used it. It is 
possible that variations in views also exist based on whether providers have used telemedicine or not.

Despite these limitations this study was able to demonstrate that at least among some providers differences exist in perceptions on the meanings of multi-dimensional and single measure results. It is likely that there are other providers that may share similar views on differences although their views in relation to decision making may differ. This suggests that there is potential added value in continuing to evaluate and understand more about these potential differences. In this case, this research demonstrates not only that these differences exist and why they should be considered but provide direction for future research to consider and compare. Even more these understandings not only inform future research on telemedicine satisfaction but can provide further insight into provider decision making on adoption and satisfaction in other IS research [38].

\section{Conclusion}

This study aimed to contribute to the knowledge on the problem of interpretation of satisfaction measures by providing insight into provider decision making when it comes to overall and multi-dimensional satisfaction evaluations. Based on the results of qualitative findings the results confirm that there exist variations in the views of providers between measures. The thematic analysis used was able to aid in developing and defining themes around provider perspectives based on the interviews. The results show that regardless of the measurements providers may be more inclined to use results of satisfaction evaluations for reassurances to confirm views that have an experiential nature. However, the kinds of views and how these reassurances are approached vary based on the measure. Single measures may provide limited sufficiency that can lead to interpretive analyses that are generally used to confirm use choices. Multi-dimensional measures aid in identifying different levels of improvement and through comparative analysis providers may use them to confirm and explain beliefs around patient experiences.

There were several limitations for this research that suggest future areas of study. The limitations are mainly around the generalizability of findings and potential contextual differences. Future research should seek to expand on these findings by using similar qualitative methods at other institutions and comparing results. This can assist in eventually developing additional theory that can be generalized around these satisfaction measurements and interpretation.

This research provides contributions for both researchers and decision makers involved in evaluating telemedicine. For researchers it is important to not only understand the variations that exist in quantitative variations between satisfaction measures but also how the differences in their perceptions may influence decision making. Decision makers should consider the variations between measures and how they may impact the problem they are trying to understand. Among the unexpected challenges that this research reveals for decision makers is that despite the lack of well-defined meaning on certain measures providers may place their own interpretations on measurements and consider them as actionable. While this might raise concerns because of the risk for potential poor decision making, providers may compensate for the lack of knowledge by basing their decisions on experiences and direct patient feedback.

\section{References}

[1] R. Vaezi, A. Mills, W. Chin, and H. Zafar, "User Satisfaction Research in Information Systems: Historical Roots and Approaches," Communications of the Association for Information Systems, vol. 38, no. 27, 2016, pp. 501-532.

[2] L. R. Kalankesh, Z. Nasiry, R. Fein, and S. Damanabi, "Factors Influencing User Satisfaction with Information Systems: A Systematic Review," Galen Medical Journal, vol. 9, 2020, p. 1686.

[3] S. Sood et al., "What is telemedicine? A collection of 104 peer-reviewed perspectives and theoretical underpinnings," Telemedicine and e-Health, vol. 13, no. 5, 2007, pp. 573-590.

[4] M. P. Manary, W. Boulding, R. Staelin, and S. W. Glickman, "The patient experience and health outcomes," New England Journal of Medicine, vol. 368, no. 3, 2013, pp. 201-203.

[5] E. Shirley, G. Josephson, and J. Sanders, "Fundamentals of Patient Satisfaction Measurement," Physician leadership journal, vol. 3, no. 1, 2016, p. 12.

[6] E. Z. Barsom, E. van Hees, W. A. Bemelman, and M. P. Schijven, "Measuring patient satisfaction with video consultation: a systematic review of assessment tools and their measurement properties," International Journal of Technology Assessment in Health Care, vol. 36, no. 4, 2020, pp. 356-362.

[7] S. Ye et al., "Telemedicine Expansion During the COVID-19 Pandemic and the Potential for TechnologyDriven Disparities," Journal of General Internal Medicine, vol. 36, no. 1, 2021, pp. 256-258.

[8] A. C. Smith et al., "Telehealth for global emergencies: Implications for coronavirus disease 2019 (COVID-19)," Journal of telemedicine and telecare, vol. 26, no. 5, 2020, pp. 309-313.

[9] S. Hajesmaeel-Gohari and K. Bahaadinbeigy, "The most used questionnaires for evaluating telemedicine services," BMC Medical Informatics and Decision Making, vol. 21, no. 1, 2021, pp. 1-11.

[10] M. T. Nawas et al., "Pilot Study of Telehealth Evaluations in Patients Undergoing Hematopoietic Cell 
Transplantation," Biology of Blood and Marrow Transplantation, vol. 26, no. 6, 2020, pp. 136-137.

[11] B. Busacca and G. Padula, "Understanding the relationship between attribute performance and overall satisfaction: Theory, measurement and implications," Marketing Intelligence \& Planning, vol. 23, no. 6, 2005, pp. 543-561.

[12] K. E. Cowan, A. J. McKean, M. T. Gentry, and D. M. Hilty, "Barriers to use of telepsychiatry: clinicians as gatekeepers," in Mayo Clinic Proceedings, 2019, vol. 94, no. 12, pp. 2510-2523: Elsevier.

[13] M. Nguyen, M. Waller, A. Pandya, and J. Portnoy, "A review of patient and provider satisfaction with telemedicine," Current allergy and asthma reports, vol. 20, no. 11, 2020, pp. 1-7.

[14] R. Vaezi, A. Mills, and W. Chin, "User satisfaction with information systems: A comprehensive model of attribute-level satisfaction," Communications of the Association for Information Systems, vol. 45, no. 1, 2019, p. 13.

[15] R. L. Oliver, Satisfaction: A behavioral perspective on the consumer. New York, NY, USA: ME Sharpe, 2010.

[16] J. L. Giese and J. A. Cote, "Defining consumer satisfaction," Academy of marketing science review, vol. 1, no. 1, 2000, pp. 1-22.

[17] J. H. Ng and B. H. Luk, "Patient satisfaction: Concept analysis in the healthcare context," Patient education and counseling, vol. 102, no. 4, 2019, pp. 790-796.

[18] S. B. MacKenzie, P. M. Podsakoff, and N. P. Podsakoff, "Construct measurement and validation procedures in MIS and behavioral research: Integrating new and existing techniques," MIS quarterly, vol. 35, no. 2, 2011, pp. 293-334.

[19] M. A. Iseli, R. Kunz, and E. Blozik, "Instruments to assess patient satisfaction after teleconsultation and triage: a systematic review," Patient preference and adherence, vol. 8, 2014, p. 893.

[20] G. Rogers, "Using Telemedicine for Pediatric Preanesthesia Evaluation: A Pilot Project," Journal of PeriAnesthesia Nursing, vol. 35, no. 1, 2020, pp. 3-6.

[21] S. Douglas et al., "Telehealth in Plastic Surgery: A Veterans Affairs Hospital Perspective," Plastic and Reconstructive Surgery Global Open, vol. 6, no. 10, 2018, p. e1840.

[22] S. Zhang, S. I. McClean, D. E. Jackson, C. Nugent, and I. Cleland, "Patient Satisfaction Evaluation of Telemedicine Applications Is Not Satisfactory," in XIII Mediterranean Conference on Medical and Biological Engineering and Computing 2013, 2014, pp. 1140-1143: Springer.

[23] S. AlDossary, M. G. Martin-Khan, N. K. Bradford, and A. C. Smith, "A systematic review of the methodologies used to evaluate telemedicine service initiatives in hospital facilities," International journal of medical informatics, vol. 97, 2017, pp. 171-194.

[24] S. A. Kamal, M. Shafiq, and P. Kakria, "Investigating acceptance of telemedicine services through an extended technology acceptance model (TAM)," Technology in Society, vol. 60, 2020, p. 101212.

[25] F. Fülöp, B. Bőthe, É. Gál, J. Y. A. Cachia, Z. Demetrovics, and G. Orosz, "A two-study validation of a single-item measure of relationship satisfaction: RAS-1," Current Psychology, 2020, pp. 1-13.

[26] M. Sarstedt and P. Wilczynski, "More for less? A comparison of single-item and multi-item measures," Die Betriebswirtschaft, vol. 69, no. 2, 2009, p. 211.

[27] N. Liu, S. Kumara, and E. Reich, "Explainable datadriven modeling of patient satisfaction survey data," in 2017 IEEE International Conference on Big Data (Big Data), 2017, pp. 3869-3876: IEEE.

[28] T. Oshagbemi, "Overall job satisfaction: how good are single versus multiple-item measures?," Journal of managerial Psychology, vol. 14, no. 5, 1999, pp. 388403.

[29] W. Wang, E. Maitland, S. Nicholas, and J. Haggerty, "Determinants of overall satisfaction with public clinics in rural China: interpersonal care quality and treatment outcome," International journal of environmental research and public health, vol. 16, no. 5, 2019, p. 697.

[30] N. Basias and Y. Pollalis, "Quantitative and qualitative research in business \& technology: Justifying a suitable research methodology," Review of Integrative Business and Economics Research, vol. 7, 2018, pp. 91-105.

[31] J. E. Sale, L. H. Lohfeld, and K. Brazil, "Revisiting the quantitative-qualitative debate: Implications for mixedmethods research," Quality and quantity, vol. 36, no. 1, 2002, pp. 43-53.

[32] S. B. Merriam, Qualitative Research : A Guide to Design and Implementation 3rd ed. San Fransicso, CA, USA: Jossey-Bass, 2009.

[33] K. Vasileiou, J. Barnett, S. Thorpe, and T. Young, "Characterising and justifying sample size sufficiency in interview-based studies: systematic analysis of qualitative health research over a 15-year period," BMC medical research methodology, vol. 18, no. 1, 2018, pp. $1-18$.

[34] G. Guest, A. Bunce, and L. Johnson, "How many interviews are enough? An experiment with data saturation and variability," Field methods, vol. 18, no. 1, 2006, pp. 59-82.

[35] V. Braun and V. Clarke, Thematic analysis. Washington DC, USA: American Psychological Association, 2012.

[36] A. von Wangenheim, L. F. de Souza Nobre, H. Tognoli, S. M. Nassar, and K. Ho, "User satisfaction with asynchronous telemedicine: A study of users of Santa Catarina's system of telemedicine and telehealth," Telemedicine and e-Health, vol. 18, no. 5, 2012, pp. 339346.

[37] E. Howarth, K. Devers, G. Moore, A. O'Cathain, and M. Dixon-Woods, "Contextual issues and qualitative research," Health Services and Delivery Research, vol. 4, no. 16, 2016, pp. 105-120.

[38] N. Menachemi, D. E. Burke, and D. J. Ayers, "Factors affecting the adoption of telemedicine - a multiple adopter perspective," Journal of medical systems, vol. 28, no. 6, 2004, pp. 617-632. 